\title{
Composite Concrete Slabs with Profiled Steel Decking: Comparison Between Experimental and Simulation Study
}

\author{
Namdeo Hedaoo ${ }^{1, \text { * }}$, Namdeo Raut ${ }^{2}$, Laxmikant Gupta ${ }^{3}$ \\ ${ }^{1}$ Department of Civil Engineering, Govt. College of Engineering, Pune, Maharashtra, India \\ ${ }^{2}$ Department of Applied Mechanics, Govt. Polytechnics, Yavatmal, Maharashtra, India \\ ${ }^{3}$ Department of Applied Mechanics, Visvesvaraya National Institute of Technology, Nagpur, Maharashtra, India \\ Email address: \\ nahedaoo@yahoo.com (N. Hedaoo),nv_raut@yahoo.com (N. Raut), lmgupta_vrce@yahoo.co.in (L. Gupta)
}

\section{To cite this article:}

Namdeo Hedaoo, Namdeo Raut, Laxmikant Gupta. Composite Concrete Slabs with Profiled Steel Decking: Comparison Between Experimental and Simulation Study. American Journal of Civil Engineering. Vol. 3, No. 5, 2015, pp. 157-169.

doi: $10.11648 /$ j.ajce. 20150305.14

\begin{abstract}
The research work is to study the behavior of the composite concrete slabs with CRIL DECKSPAN type profiled steel decking by experimental and simulation study. The slab is created by composite interaction between concrete and steel deck with rolled embossments to improve their shear-bond characteristics. However, it fails under longitudinal shear-bond due to the complex phenomenon of shear behavior. Therefore, an experimental full-size tests has been carried out to investigate the shear-bond strength under flexural test in accordance with Eurocode 4: Part 1.1. Eighteen specimens are split into six sets of three specimens each in which all sets are tested for different shear span lengths under static and cyclic loading on simply supported slabs. The full-size finite element (FE) modeling and analysis of the composite slabs is presented, in which the shear-bond interaction between the concreteand steel deck is simulated by the use of interface contact elements. The FE analysis is verified and validated by comparing the experimental results. Comparisons of the experimental and simulation results indicate that the FE analysis agrees well with the test results, and is capable of predicting the behavior and the load carrying capacity of composite slabs.
\end{abstract}

Keywords: Composite Slab, Full-Size Test, m-k Method, Interface Contact Element, Finite Element Analysis

\section{Introduction}

Over the years, a composite slab has proved to be one of the simpler, faster, lighter and economical constructions in steel framed building systems. The system is well accepted by the construction industry due to the many advantages over other types of floor systems [1-2]. In the last decade, the construction industry is looking beyond conventional methods and exploring for the better to win over today's challenges and therefore composite slab construction is one of the viable options.

The casting of concrete is carried out on profiled steel decking as permanent formwork which is supported by floor beams. The force transfer mechanism of composite slabs can be characterized by three failure types: (i) flexural failure, (ii) longitudinal shear failure and (iii) vertical shear failure. The longitudinal shear failure is the most common failure type which is affected by the interlock on the concrete-steel deck interface. The strength of the longitudinal shear bond also depends on many factors, among which include the shape of the steel deck profile, type and frequency of embossment, thickness of steel decking, arrangement of load, length of shear span, slenderness of the slab and type of end anchorage. Because of these numerous influencing factors, it is not possible to provide representative design values that can be applied to all slab conditions. This is why the design of composite slabs requires full-size tests to determine the shear transferring mechanism and the longitudinal shear-bond strength. Two design methods for the verification of composite slabs are given in Eurocode 4 Part 1-1: the $m-k$ method and the partial shear connection method.

In the experimental study, eighteen full-size composite slab specimens consisting of cold-formed trapezoidal profiled steel decking with rectangular dishing type embossments are built and tested in accordance with the Eurocode 4:Part1.1 to determine: (1) the structural behavior; (2) the load carrying capacity; and (3) to provide the necessary information to validate the simulation procedures. Also to study the loaddeflection curves, load-end slip curves and failure modes are 
subject to imposed loads. The steel decks (CRIL DECKSPAN) are manufactured and supplied by Colour Roof India Limited, Mumbai, INDIA. A one-way, single-span, simply-supported slab specimens are tested using M20 grade of concrete subjected to two equal line loads placed symmetrically at six different shear span lengths.

The full-size FE modeling and analysis is carried out to investigate the behavior of composite slabs considering the intermediate stiffeners on top and bottom flange of trapezoidal profiled steel decking using the software ANSYS 11. Effect of embossments is not considered in modeling. Nonlinear three dimensional models are proposed, in which all main structural parameters (concrete slab, profiled steel sheeting and its interface) and associated nonlinearities are included. The FE analysis requires data from experimental full-size tests as an input to the model. The data, which is the interaction property between the concrete and the steel deck in the form of longitudinal shear bond strengthis the most important factor that affects the accuracy of the results.

The purpose of the current research is to study the FE modeling and analysis results of composite slabs which can predict the load-deflection behavior, load-end slip behavior and failure modes are presented and compared with those results of the experimental full-size tests. A parametric study is carried out and factors like different shear span lengths that influence the behavior and load carrying capacity of the composite slabs are discussed.

\section{Review of Literature}

Most of the full-size tests done in the past by researchers have shown that the load carrying capacity of composite slabs is governed by the longitudinal shear bond failure. Porter and Ekberg [3-4] have carried out a large number of experimental studies, in which the design equations for the shear bond capacity are derived from the data collected from a series of full-scale performance tests on one-way single span slabs and developed by establishing the linear regression relationship. The method is further verified and supported by Wright et al. [5]. A new simplified method is developed by Crisinel et al. [6] and Mohan Ganesh [7] which provides the design of composite slabs by its critical crosssection and partial interaction method respectively. To simplify full-scale tests and small-scale tests are also proposed by push-out/pull-out tests and slip block test respectively. Marimuthu et al. [8] carried out experimental investigations on full-scale slab specimens to determine the shear bond characteristics for composite slabs.

For composite slabs, various simulation models have been proposed using different finite element software packages. This study has been driven by the significance of providing low cost tools with higher accuracy. Baharom and Xiao [9] performed finite element analysis using software ANSYS to study the effect of longitudinal slip model in ribbed decking composite slab. Full and partial interaction model is used to study the influence of slip in the model and to investigate the difference in composite slab behavior under both modeling techniques. For slip model, the interface element is developed between concrete and steel decking which include link element and spring element. For full-interaction model, concrete and steel decking used the same nodes.

The FE modeling and analysis of the ultimate behavior of one and two-way composite slabs are carried out by Eldib et al. [10] using software COSMOS/M 2.6 and validated by full-size tests. The effects of cold steel straps at the bottom steel deck flange perpendicular to corrugation direction for two-way slabs, embossments flattening, slab aspect ratio and slab slenderness ratio are investigated. The concrete slab is modeled using solid element and steel deck is modeled using shell element. The steel reinforcement mesh, slip interaction and perpendicular interaction at interface between steel deck and concrete is modeled by truss element.

The shear bond interaction between the concrete and the steel deck in composite slabs is a highly nonlinear contact problem where sticking, sliding and frictional phenomena are present at the interface. The shear bond interactions of the composite slabs are treated as a unilateral contact problem and simplified as a two dimensional contact model. The contact pair is constructed by using area to area contact finite element by Tsalkatidis and Avdelas [11]. More recently, a universal FE approach of composite slabs is presented, in which the shear bond interaction between the concrete and the steel deck is treated as a contact problem considering adhesion and friction. The FE analysis using the contact model is further carried out in study of the load behavior of composite slabs in full-size flexural bending by Chen and Shi [12].

The review of literature based on experimental study, shows that the strength of longitudinal shear bond achieved depends on many factors, among which include the shape of steel deck profile, type and frequency of embossments, thickness of steel decking, length of shear span and slenderness of the slab. Currently an accurate determination of load carrying capacity for a new profiled steel decking type is possible only by full-size testing in accordance with Eurocode 4. The purpose of the tests is to provide data for the design of composite slabs using shear-bond method. In the case of simulation study, the FE modeling and analysis is carried out on full-size models to investigate the longitudinal shear-bond behavior of composite slabs. In every case the layout of the models is the following: the concrete is modeled by solid elements, the steel decking is modeled by shell elements and the shear connection between the concrete and the profiled steel decking is modeled by different non-linear interface contact elements.

\section{Experimental Study}

\subsection{General}

The experimental study used for the composite slabs with profiled steel decking consists of static and cyclic tests on six sets of full-size slab specimens subjected to six different shear span lengths [13]. For each set of three specimens, one specimen is tested to failure under static loading and other 
two specimens are tested for cyclic loading [14]. Subsequent sets of tests are conducted in similar manner with remaining shear spans. The aim of the experiments presented here, is to provide the fundamental information on the behavior and load carrying capacity of composite slabs with realistic geometric and material characteristics. As has already been mentioned, the whole experimental procedure is performed to the specifications of Eurocode 4: Part 1.1.

\subsection{Preparation of Slab Specimens}

All composite slab specimens are cast with full supports on the plain surface concrete flooring in the Composite Testing Laboratory. Figure 1 illustrates the geometric shape of the trapezoidal profiled steel decking sheet. A total of eighteen full-size composite slab specimens are constructed with $102 \mathrm{~mm}$ nominal depth, $830 \mathrm{~mm}$ width and $3000 \mathrm{~mm}$ span. The thickness of the concrete above the flange is 50 $\mathrm{mm}$ while depth of the profiled steel deck is $52 \mathrm{~mm}$ as shown in Figure 2. All slabs are constructed utilizing M20 grade of concrete obtained from a hand mixing method. The $70 \mathrm{~mm}$ depth of slabs are cast first, over which mild steel mesh reinforcement of four steel bars, $6 \mathrm{~mm}$ in diameter, are placed at a center to center distance of $250 \mathrm{~mm}$ in the longitudinal direction and twelve at a spacing of $250 \mathrm{~mm}$ in transverse direction to complete cross sectional dimension of the slab and tied with binding wires [15]. Mild steel mesh reinforcement is used as shrinkage and temperature control reinforcements as specified in the ASCE specification [16]. Remaining $32 \mathrm{~mm}$ depth of the slab is cast and the top surface is finished by proper compaction of concrete. The test parameters used in this study are summarized in Table 1.

Table 1. Test parameters.

\begin{tabular}{|c|c|c|c|c|c|c|c|c|}
\hline Test no. & $\begin{array}{l}\text { Slab } \\
\text { designation }\end{array}$ & $\begin{array}{l}\text { Type of } \\
\text { loading }\end{array}$ & $\begin{array}{l}\text { Effective span, } \\
L(\mathrm{~mm})\end{array}$ & $\begin{array}{l}\text { Shear span, } \\
L_{s}(\mathrm{~mm})\end{array}$ & $\begin{array}{l}\text { Cover width, } b \\
(\mathrm{~mm})\end{array}$ & $\begin{array}{l}\text { Nominal depth, } \\
h_{t}(\mathrm{~mm})\end{array}$ & $\begin{array}{l}\text { Conc. comp. strength, } \\
f_{c k}\left(\mathrm{~N} / \mathrm{mm}^{2}\right)\end{array}$ & $\begin{array}{l}\text { Steel deck } \\
\text { thickness, } t(\mathrm{~mm})\end{array}$ \\
\hline 1 & $\begin{array}{l}\text { EX- } \\
01 \mathrm{ST} 300\end{array}$ & static & 2700 & 300 & 830 & 102 & 20.8 & 0.8 \\
\hline 2 & $\begin{array}{l}\text { EX- } \\
02 \mathrm{CT} 300\end{array}$ & cyclic & 2700 & 300 & 830 & 102 & 20.8 & 0.8 \\
\hline 3 & $\begin{array}{l}\text { EX- } \\
03 \text { CT300 }\end{array}$ & cyclic & 2700 & 300 & 830 & 102 & 20.8 & 0.8 \\
\hline 4 & $\begin{array}{l}\text { EX- } \\
04 S T 375\end{array}$ & static & 2700 & 375 & 830 & 102 & 20.8 & 0.8 \\
\hline 5 & $\begin{array}{l}\text { EX- } \\
05 \mathrm{CT} 375\end{array}$ & cyclic & 2700 & 375 & 830 & 102 & 20.8 & 0.8 \\
\hline 6 & $\begin{array}{l}\text { EX- } \\
06 \mathrm{CT} 375\end{array}$ & cyclic & 2700 & 375 & 830 & 102 & 20.8 & 0.8 \\
\hline 7 & $\begin{array}{l}\text { EX- } \\
07 \text { ST450 }\end{array}$ & static & 2700 & 450 & 830 & 102 & 20.8 & 0.8 \\
\hline 8 & $\begin{array}{l}\text { EX- } \\
08 \mathrm{CT} 450\end{array}$ & cyclic & 2700 & 450 & 830 & 102 & 20.8 & 0.8 \\
\hline 9 & $\begin{array}{l}\text { EX- } \\
\text { 09CT450 }\end{array}$ & cyclic & 2700 & 450 & 830 & 102 & 20.8 & 0.8 \\
\hline 10 & $\begin{array}{l}\text { EX- } \\
10 \text { ST525 }\end{array}$ & static & 2700 & 525 & 830 & 102 & 20.8 & 0.8 \\
\hline 11 & $\begin{array}{l}\text { EX- } \\
11 \mathrm{CT} 525\end{array}$ & cyclic & 2700 & 525 & 830 & 102 & 20.8 & 0.8 \\
\hline 12 & $\begin{array}{l}\text { EX- } \\
12 \mathrm{CT} 525\end{array}$ & cyclic & 2700 & 525 & 830 & 102 & 20.8 & 0.8 \\
\hline 13 & $\begin{array}{l}\text { EX- } \\
13 \text { ST600 }\end{array}$ & static & 2700 & 600 & 830 & 102 & 20.8 & 0.8 \\
\hline 14 & $\begin{array}{l}\text { EX- } \\
14 \mathrm{CT} 600\end{array}$ & cyclic & 2700 & 600 & 830 & 102 & 20.8 & 0.8 \\
\hline 15 & $\begin{array}{l}\text { EX- } \\
15 \mathrm{CT} 600\end{array}$ & cyclic & 2700 & 600 & 830 & 102 & 20.8 & 0.8 \\
\hline 16 & $\begin{array}{l}\text { EX- } \\
16 \text { ST675 }\end{array}$ & static & 2700 & 675 & 830 & 102 & 20.8 & 0.8 \\
\hline 17 & $\begin{array}{l}\text { EX- } \\
17 \mathrm{CT} 675\end{array}$ & cyclic & 2700 & 675 & 830 & 102 & 20.8 & 0.8 \\
\hline 18 & $\begin{array}{l}\text { EX- } \\
18 \mathrm{CT} 675\end{array}$ & cyclic & 2700 & 675 & 830 & 102 & 20.8 & 0.8 \\
\hline
\end{tabular}

Note: Slab designation in the form of "i-j-k-l" where i,j,k and 1 are variables indicating the experimental study, serial number of test specimen, static or cyclic test and shear span length (mm) respectively. Hence, 'EX-01ST300' refers to the specimen using experimental study, $1^{\text {st }}$ test specimen, static loading and 300 mm shear span. 


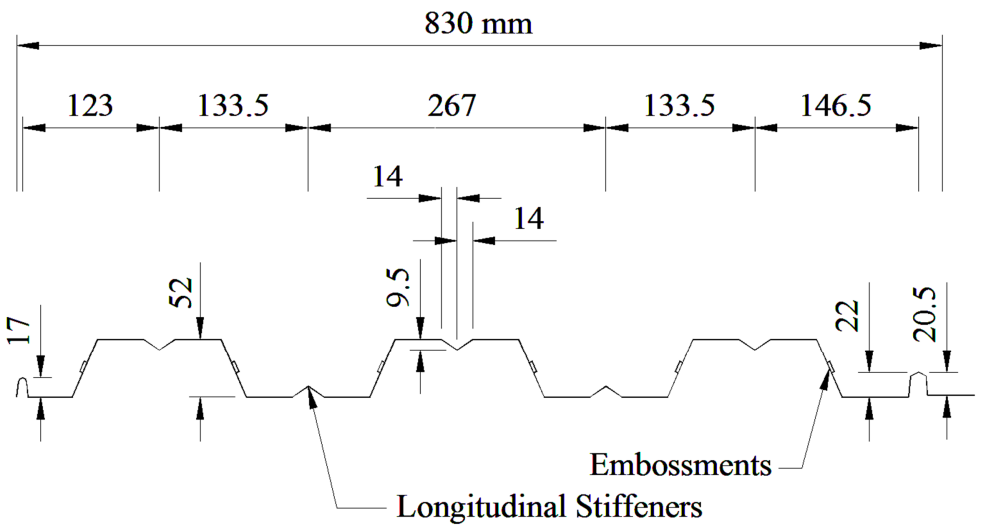

Figure 1. Deck cross-section and dimensions.

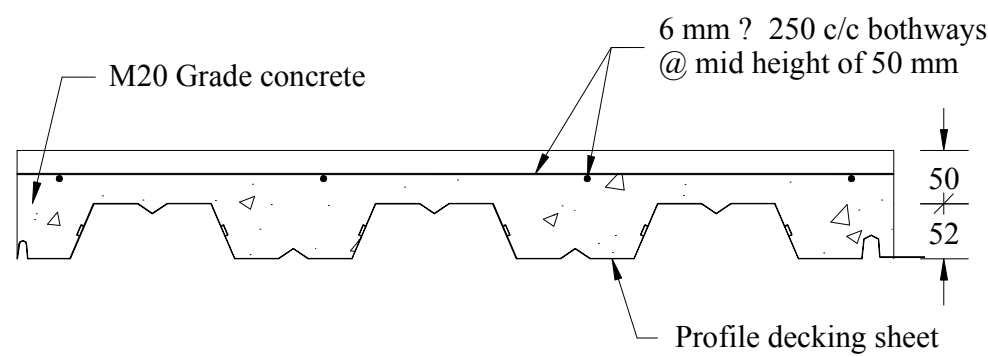

Figure 2. Cross-section of test specimen.

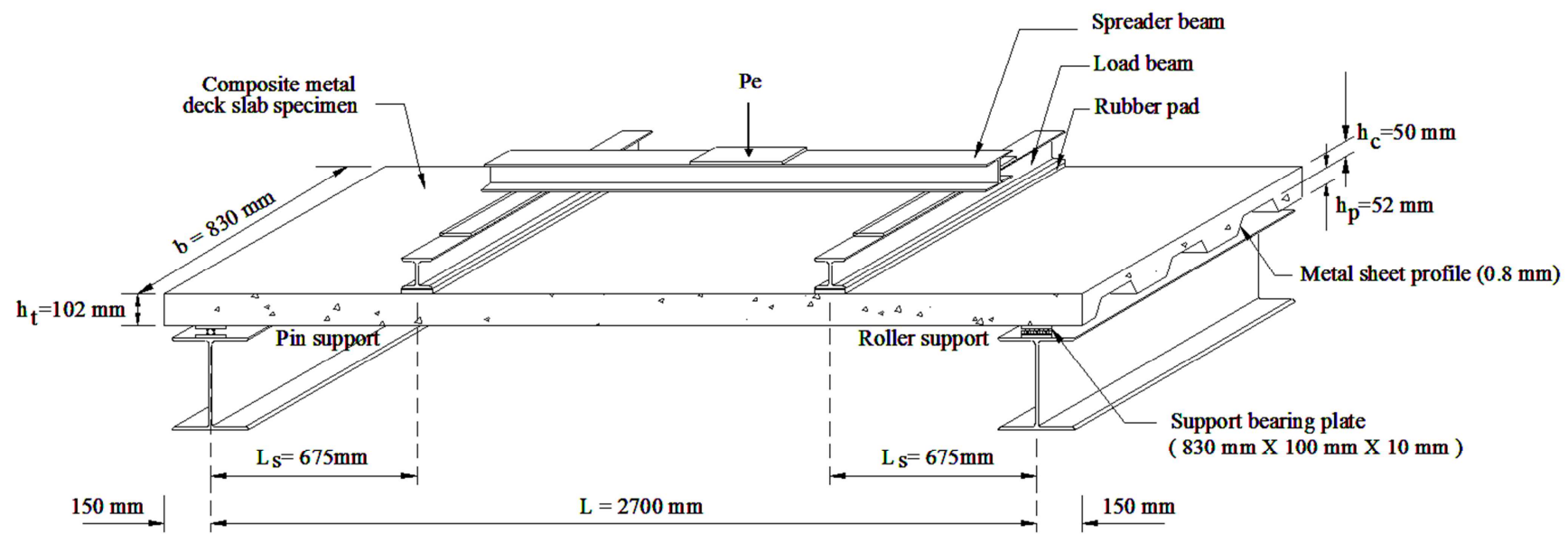

Figure 3. Schematic view of the experimental test set-up.

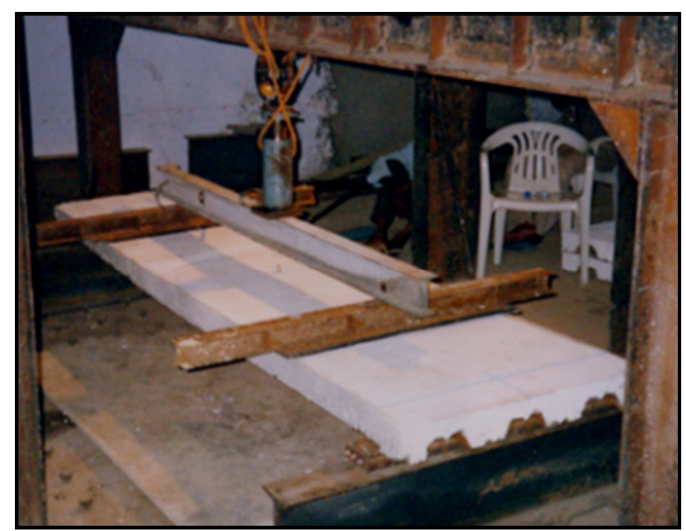

Figure 4. Experimental test set-up.
The curing period of all eighteen slabs was 28 days. Despite all required preventive measures during transport phase, specimen EX-12CT525 (Figure 16.d) presented premature slippage, probably due to riding procedure. Hence there are no results recorded for the specimen and invalidating test.

\subsection{Arrangement}

The specimens are placed carefully and symmetrically over the experimental set-up using a crane and belts. The schematic view of arrangement for the simply supported composite slab configuration with an effective span of $2.7 \mathrm{~m}$ subjected to two symmetrically located uniformly distributed line loads is shown in Figure 3. In order to simulate simple support conditions, roller and hinge supports are specially fabricated for study. These supports are extended along the 
whole width of the specimen. Loading is applied by a single hydraulic jack system mounted on structural spreader beam section (ISMB 150), beneath the structural load beams (2 ISMC 100, placed back to back) and load is measured with the help of cell at the point of application. Uniform loading is applied by inflating a $15 \mathrm{~mm}$ thick by $100 \mathrm{~mm}$ wide hard rubber pad, which is confined by the top surface of the test slab. A steel plate with $10 \mathrm{~mm}$ thickness by $100 \mathrm{~mm}$ width is placed on the top of the pad. Fig. 4 shows the complete experimental set-up.

\subsection{Loading Procedure}

One slab of each group is subjected to static loading until failure. The specimens are placed over supporting rollerhinge supports and loading points are marked on shear span. Load is applied incrementally by single hydraulic jack system. Rate of loading is adjusted in such a way that failure did not occur in less than one hour. Rate of loading adopted for static test is $0.1 \mathrm{~mm} / \mathrm{s}$. Tests are determined as per the calculated design value, or discontinued when the deflections reaches $L / 50$.

Cyclic loading is required to be implemented in the tests prior to the static loading. Hence, two specimens under each shear span are subjected to preliminary cyclic loading. This cycling loading ensures that any kind of chemical bond formed between the concrete and the steel is removed and the static load that is later applied would provide the true indication of the mechanical bond formed by the embossment. Slab is subjected to 3 cycles of loading applied in a time span of three hours according to BS 5950: Part 4:1994 [14]. The next loading sequence is of a static nature.

The vertical mid-span deflection is measured using microlevel equipment. For end-slip measurements, two dial gauges are attached to one end of the composite slab in order to measure the relative slip between the concrete and the steel deck. Average value of the total load at failure (average of one statically loaded and two cyclically loaded) is calculated for each set of specimen.

\subsection{Experimental Results}

Figure 5 shows the load-deflection curves for shear span $\left(L_{s}\right)=450 \mathrm{~mm}$. For the shear spans, $300 \mathrm{~mm}, 375 \mathrm{~mm}$ and $450 \mathrm{~mm}$, first initial shear cracks formed near the loading point and then flexural cracks formed near center of span at the bottom of the concrete.

Figure 6 shows the load-deflection curves for shear span $\left(L_{s}\right)=600 \mathrm{~mm}$. For the shear spans, $525 \mathrm{~mm}, 600 \mathrm{~mm}$ and
$675 \mathrm{~mm}$, first initial flexural cracks formed at the bottom of the concrete near center of span and then shear cracks formed near loading points. Also flexural cracks are formed in between loading points. In Figures 5 and 6, both the static and the cyclic sequence of tests are plotted.

Figure 7 shows the observed typical visible crack formation for $L_{s}=600 \mathrm{~mm}$.

Figure 8 shows the differential movement of the concrete slab and the steel deck for $L_{s}=600 \mathrm{~mm}$. Slip is observed from both side of profile towards center of slab.

In cyclic test, the behavior and capacity are slightly lesser than obtained in case of the static loading.

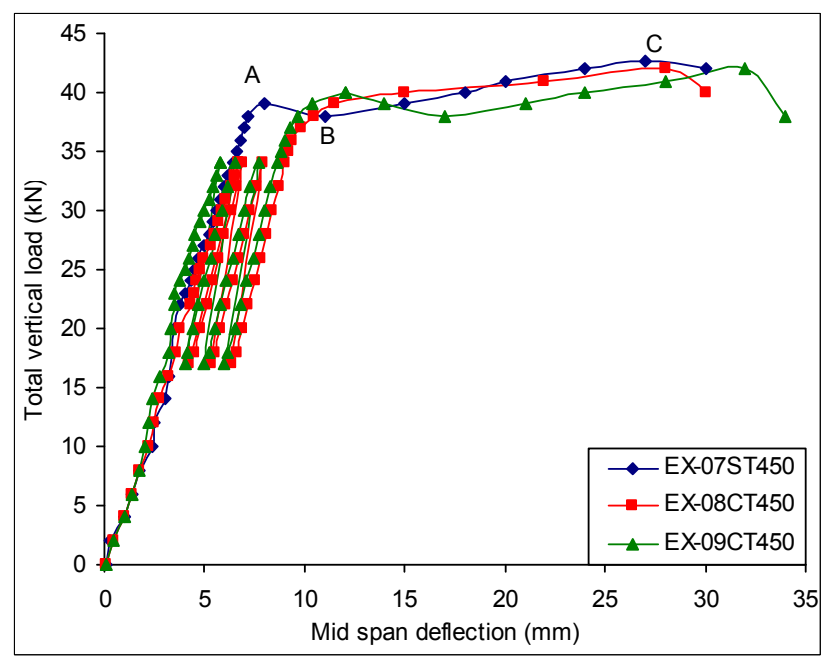

Figure 5. Load-deflection curves for $L_{s}=450 \mathrm{~mm}$.

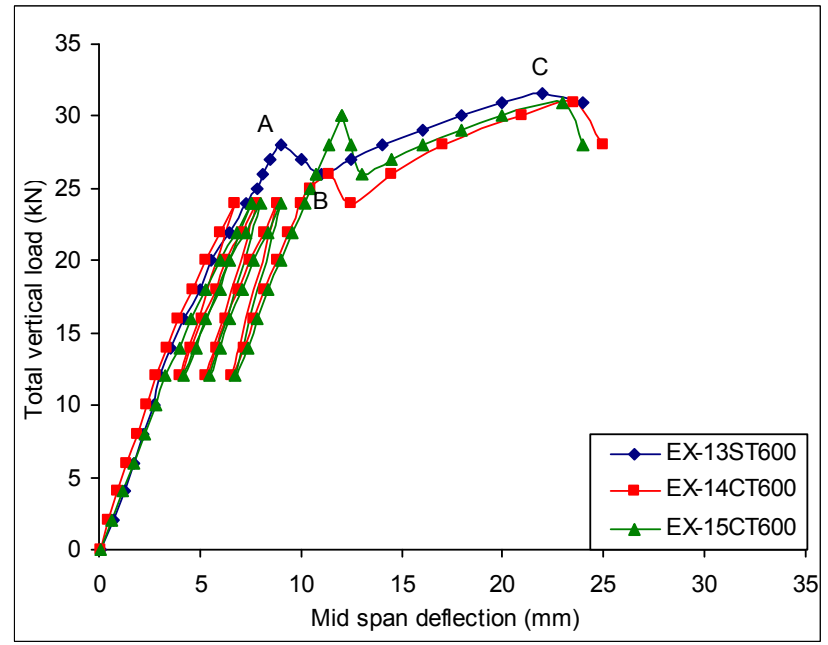

Figure 6. Load-deflection curves for $L_{s}=600 \mathrm{~mm}$.

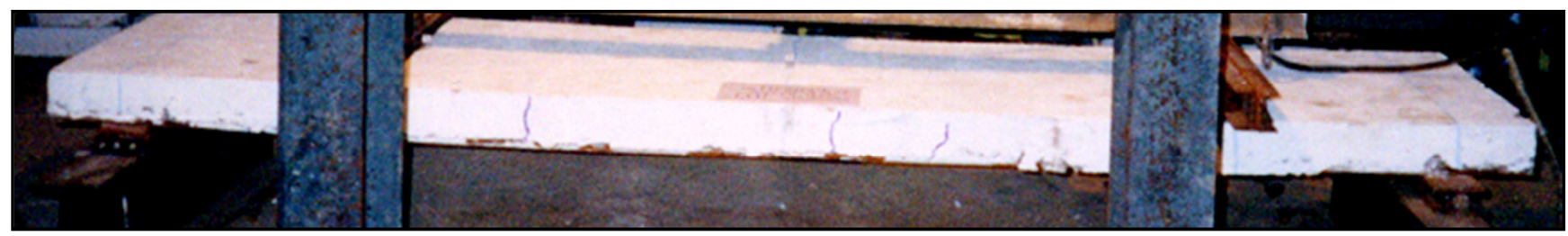

Figure 7. Crack formation for $L_{s}=600 \mathrm{~mm}$ at the ultimate stage. 


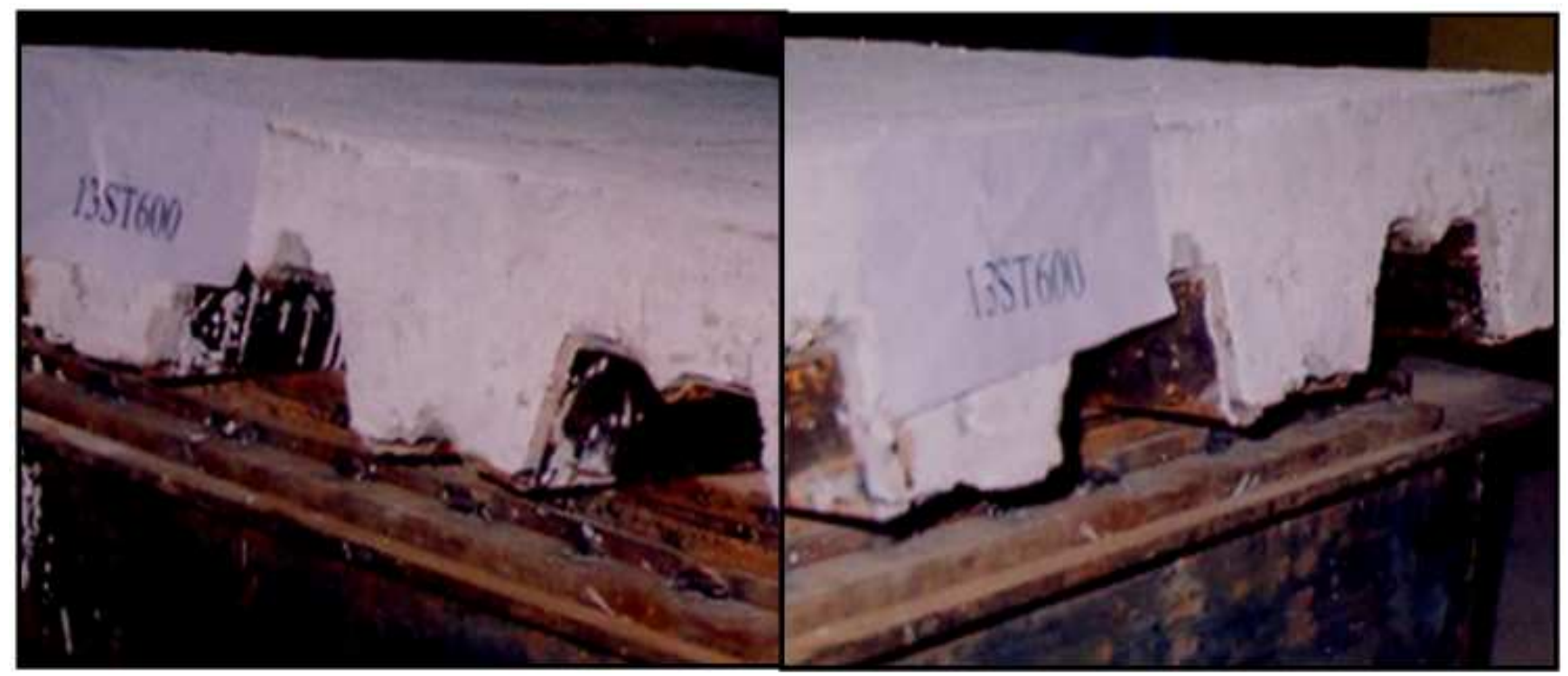

Figure 8. Typical end slips for $L_{s}=600 \mathrm{~mm}$ from left \& right side of specimen

\section{Simulation Study}

\subsection{Development of the Simulation (FE) Model}

An assembly of finite elements represents the concrete slab and profiled steel decking, connected together by interface contact elements and friction phenomena of the surfaces, has formed the basis for modeling of composite slabs. Three-dimensional nonlinear FE modeling and analysis of composite slabs are carried out using ANSYS 11 [17]. Input via a command text-based format is chosen for analysis.

In the preliminary development of the FE model, nonlinear material properties of concrete and steel decking are taken from the laboratory test results and values are given in Tables 2 and 3. Contact problems are highly non-linear and require significant computer resources to solve, since an automatic control of time stepping is provided. The behavior of several finite element types is studied under different contact conditions to choose values more appropriate for a realistic simulation.

Selection of proper 3-D point to point contact element and combination element between the concrete and steel decking are tried to determine a suitable combination that produced acceptable results. Once correct material properties and element size are obtained, models are expanded to study the behavior and strength of composite slabs.

\subsection{Structural Model}

Owing to symmetry in geometry, loading and boundary conditions, only a half of the slabs are modeled as shown in Figure 9. Symmetry exists around the middle of the span and slab width $[9,11]$. Final dimensions of the composite slab are length $*$ width $_{* \text { height }}=1350 * 400.5 * 102 \mathrm{~mm}$ and these coincide with those of the experimental set-up.

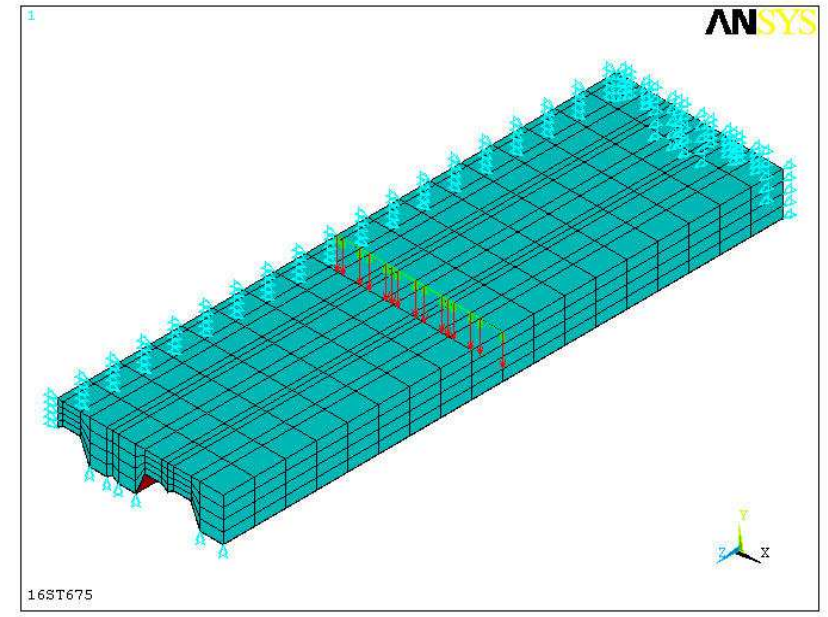

Figure 9. FE model grid, loading and boundary conditions.

Concrete slab is modeled with 8-node solid element (SOLID 65) while the profiled steel decking is modeled with 4-node finite strain shell element (SHELL 181) [11, 18]. Steel decking elements located underneath concrete slab elements are offset from the bottom of concrete elements at a distance $(0.3746 \mathrm{~mm})$ half of decking thickness [19].

Concrete slab-steel decking interface is modeled with three - dimensional point to point contact element (CONTAC 52) and combination element (COMBIN 40) in order to achieve composite action. If only CONTAC element is used, analysis would fail at an unrealistically low load. The CONTAC element is used for its abilities to prevent overlapping. However, a COMBIN element is used to increase shear bond strength. The contact stiffness values in terms of shear stress are estimated from the results of full - size tests (Figure 4) with the gap initially closed and not in sliding [19 - 22]. To model a composite slab, it is necessary to allow adjacent steel and concrete to slip relative to each other when bond strength or shear bond capacity has been exceeded. Relative 
movement of steel decking and concrete (when facing each other) must be controlled so that they are not able to move through each other, but are free to separate.

\subsection{Application of Load, Boundary Conditions and Numerical Control}

A roller support is provided at the slab end to nodes of the bottom flange of steel decking. Nodes at side face of concrete, at edges of steel decking along slab length, and at mid-span are given appropriate boundary conditions to simulate continuity of slab in lateral direction and half span model in the longitudinal direction $[9,11,19]$. Thus, model size and computational time have been reduced significantly. Load is specified by a prescribed maximum vertical displacement at concrete top fiber nodes where two equivalent line loads of equal magnitudes are incrementally applied to model to overcome convergence problems (Figure 9). Tolerance associated with this convergence criterion (CNVTOL command of ANSYS) and load step increments are varied in order to solve potential numerical problems. NewtonRaphson method is used as the incremental-iterative solution process. The convergence procedure is force-based and thus considered absolute.

\subsection{Material Modeling of Concrete}

For the concrete, the nonlinear material simulation of the ANSYS 11 software program is used. This includes both cracking and crushing failure modes. This observation is consistent with observation of slab behavior during test where concrete did not fail by crushing but rather separated by excessive tensile cracking due to slip.A similar observation is reported by Abdullah and Luttrell [19, 23]. The concrete elements in top most layer are assigned a linear elastic property where no cracking is allowed. This is done to avoid convergence problems where the model could become numerically unstable before reaching ultimate load if crack is allowed all the way up to the top most layer. The concrete properties applied in model are given in Table 2.

Table 2. Concrete properties used in the FE model.

\begin{tabular}{ll}
\hline Concrete properties & Values \\
\hline Density & $2500 \mathrm{kN} / \mathrm{m}^{3}$ \\
Characteristic cylinder strength of concrete & $20.8 \mathrm{~N} / \mathrm{mm}^{2}$ \\
Elastic modulus & $21572 \mathrm{~N} / \mathrm{mm}^{2}$ \\
Poisson ratio & 0.2 \\
Ultimate uniaxial tensile strength & $2.08 \mathrm{~N} / \mathrm{mm}^{2}$ \\
\hline
\end{tabular}

A Multilinear Isotropic Hardening (MISO) is used to model the stress-strain curve of concrete material as shown in Figure 10. The von Mises yield criteria uses along with the William and Warnke five parameter model to define the failure criterion $[9,11,24]$. The modulus of elasticity of concrete $\left(E_{c}\right)$ is based on the equation $[9,25]$ :

$$
\mathrm{E}_{\mathrm{c}}=4730 \sqrt{\mathrm{f}_{\mathrm{ck}}}
$$

Compressive uniaxial stress-strain relationship for the concrete model is obtained using following equations to compute the multilinear isotropic stress-strain curve for concrete:

$$
\begin{gathered}
f=\frac{E_{c}}{1+\left(\frac{\varepsilon}{\varepsilon_{0}}\right)^{2}} \\
\varepsilon_{0}=\frac{2 f_{c k}}{E_{c}} \\
E_{c}=\frac{f}{\varepsilon}
\end{gathered}
$$

In which $f_{c k}$ is the characteristic cylinder strength of concrete, $f$ is the stress at any strain $\varepsilon, \varepsilon$ is the strain at stress $f$ and $\varepsilon_{0}$ is the strain at the ultimate compressive strength $f_{c k}$.

Multilinear isotropic stress-strain implemented requires first point of curve to be defined by the user. It must satisfy Hooke's Law;

$$
\mathrm{E}=\frac{\sigma}{\varepsilon}
$$

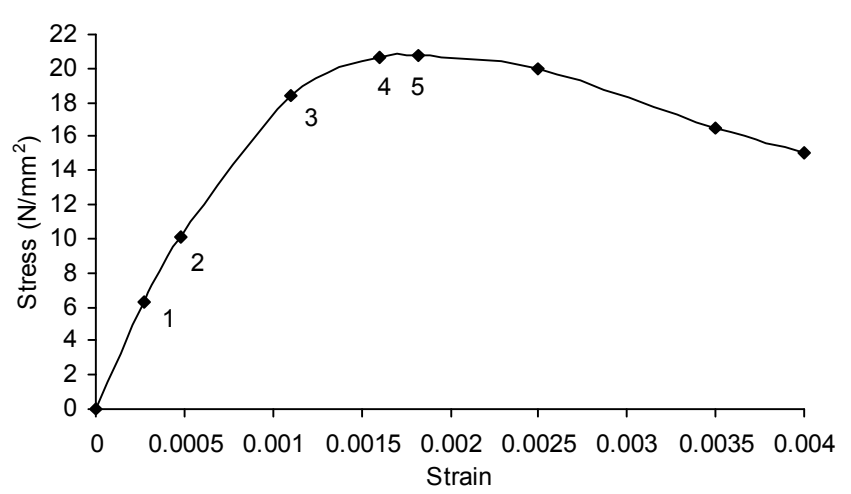

Figure 10. Uniaxial stress-strain curve for concrete.

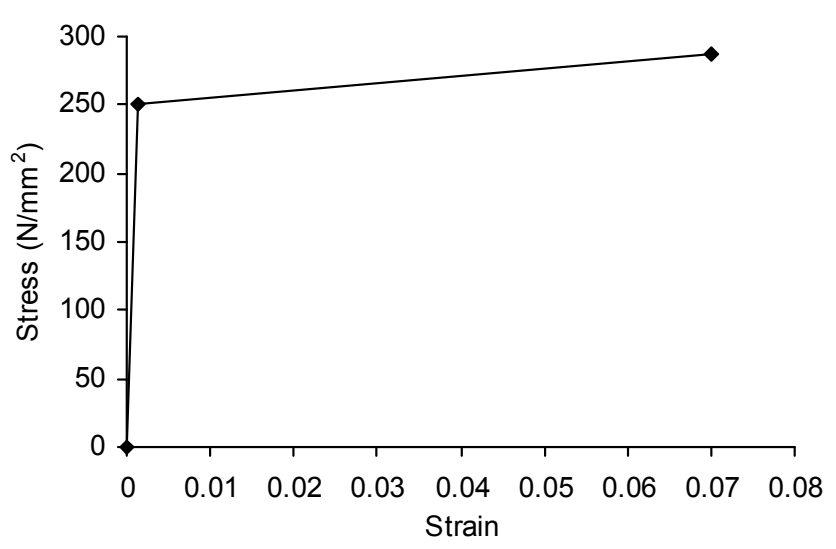

Figure 11. The elasto-plastic stress-strain curve for steel decking.

Multilinear curve is used to help with convergence of nonlinear solution algorithm. Point 1 , defined as $0.30 f_{c k}$, is calculated in linear range (Equation 4). Points 2, 3, and 4 are calculated from Equation 2 with $\varepsilon_{0}$ obtained from Equation 3. 
Stresses are calculated for every value of Strain. Point 5 is defined at $f_{c k}$ and $\varepsilon_{0}=0.003$ indicating traditional crushing strain for unconfined concrete.

\subsection{Material Model for Profiled Steel Decking}

The steel decking is modeled by shell element and is well suited for large strain/displacement during failure. The constitutive material law selected for steel decking is bilinear elastoplastic strain hardening (BISO) model using the von Mises yield criterion. The material model is determined for $0.8 \mathrm{~mm}$ thick plate and the characteristics are given in Table 3 , and Figure 11. The material of steel is considered as homogenous and isotropic.

Table 3. Steel decking properties used in the FE model.

\begin{tabular}{ll}
\hline Steel decking properties & Values \\
\hline Density & $7850 \mathrm{kN} / \mathrm{m}^{3}$ \\
Elastic modulus & $210000 \mathrm{~N} / \mathrm{mm}^{2}$ \\
Yield stress & $250 \mathrm{~N} / \mathrm{mm}^{2}$ \\
Ultimate tensile strength & $287.5 \mathrm{~N} / \mathrm{mm}^{2}$ \\
Poisson ratio & 0.3 \\
\hline
\end{tabular}

Friction which develops in the steel-concrete interface is not deemed negligible; instead, a constant friction coefficient of 0.20 is considered $[4,11]$.

\subsection{Material Model for Interface Contact Element}

The horizontal shear interaction between the concrete and the steel deck is modeled by the contact element as discussed in section 4.2 .
The COMBIN 40 is defined by two nodes, two spring constants $\mathrm{K} 1$ and $\mathrm{K} 2$ (Element stiffness = Force/Length), a damping coefficient $\mathrm{C}$, a gap size GAP (length), and a limiting sliding force FSLIDE. The FSLIDE value represents absolute value of spring force that must be exceeded before sliding occurs.

The CONTACT 52 is defined by two nodes, two stiffnesses $\left(K_{n}\right.$ and $\left.K_{s}\right)$, an initial gap or interference (GAP), and initial element status (START). Orientation of the interface is defined by node locations. Only material property used is the interface coefficient of friction $\mu$.

If rigid Coulomb friction model is selected in the ANSYS, $K_{s}$ is not used, and elastic sticking capability is removed. This option is useful for displacement controlled problems where sliding dominates.

\subsection{Simulation Results}

In Figures 12 to 15, FE analysis results are presented for the specimen 16ST675. These results depict the behavior of the proposed simulation model.Maximum central load is set equal to $29 \mathrm{kN}$ in agreement with the experimental outcome. Figure 12 shows deformation of composite slab under loading is depicted. Figure 13 and 14 shows deflection of profiled steel decking and composite slab at the time of the maximum vertical load is plotted. Longitudinal slip at the interface of the composite slab is shown in Figure 15 and is equal to $1.8 \mathrm{~mm}$. Results of experimental (static and cyclic) and FE analysis are presented on the load-deflection curves as shown in Figure 16(a)-(f) and load-end slip curvesas shown in Figure17(a)-(f).
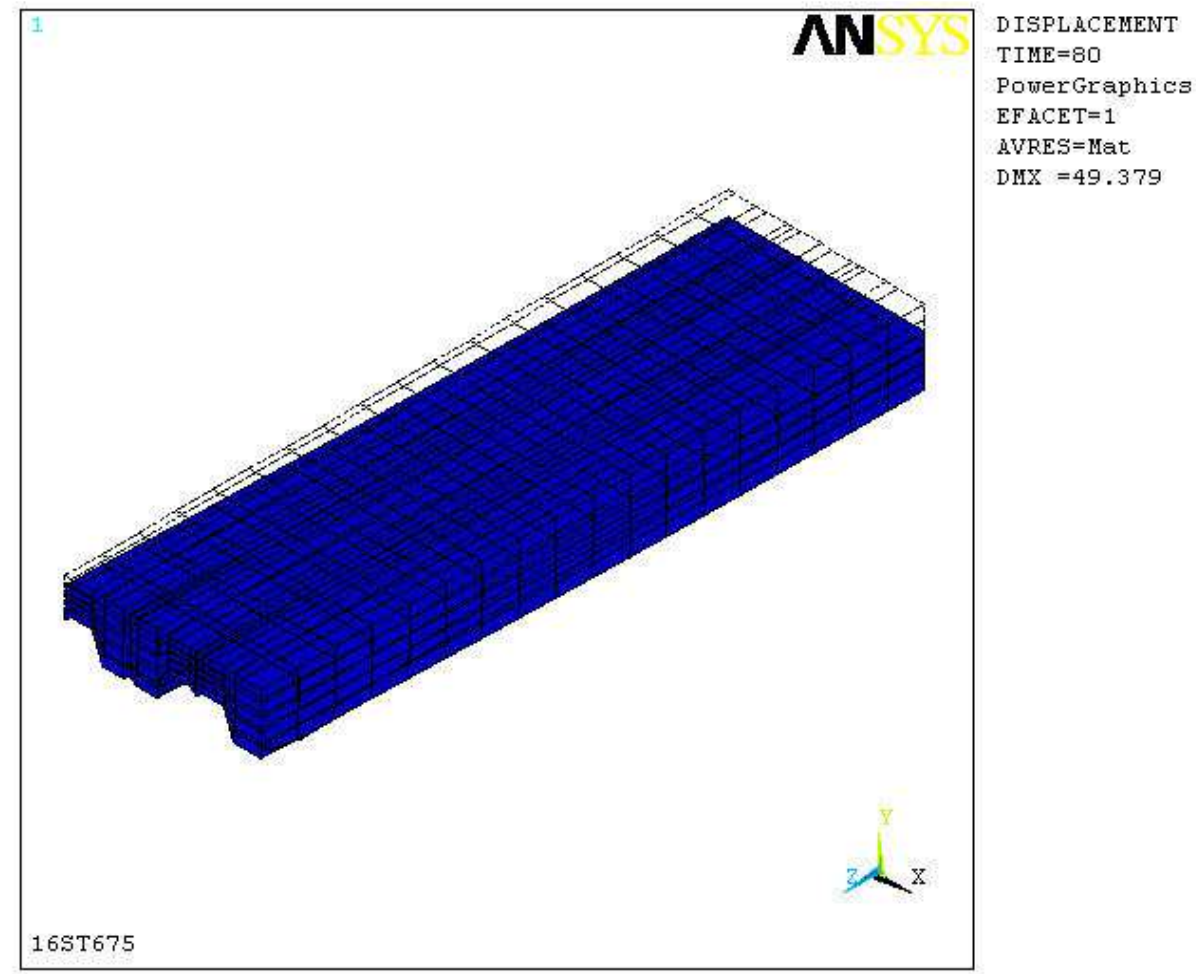

Figure 12. Deformation of composite slab. 


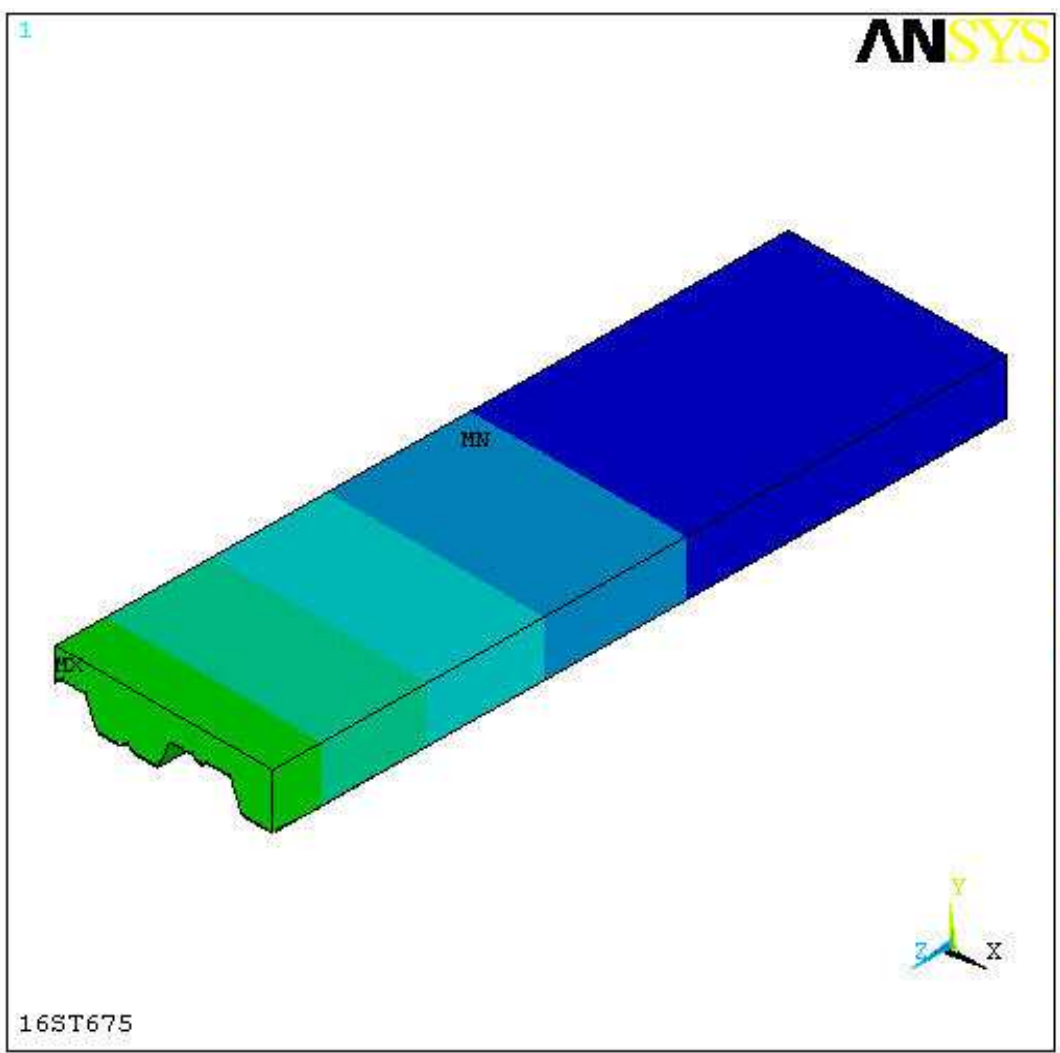

NODAL SOLUTION TIME $=26$

RSYS $=0$

PowerGraphics

EF ACET $=1$

AVRES $=$ Mat

$\mathrm{DMX}=10.468$

$\mathrm{SMN}=-10.467$

$\mathrm{SMX}=2.798$

$-10.467$

$-8.993$

$-7.519$

$-6.045$

$-4.571$

$-3.097$

$-1.623$

$-.149468$

1.324

2.798

Figure 13. Deflection (10.468 mm) of composite slab at load of $26 \mathrm{kN}$.

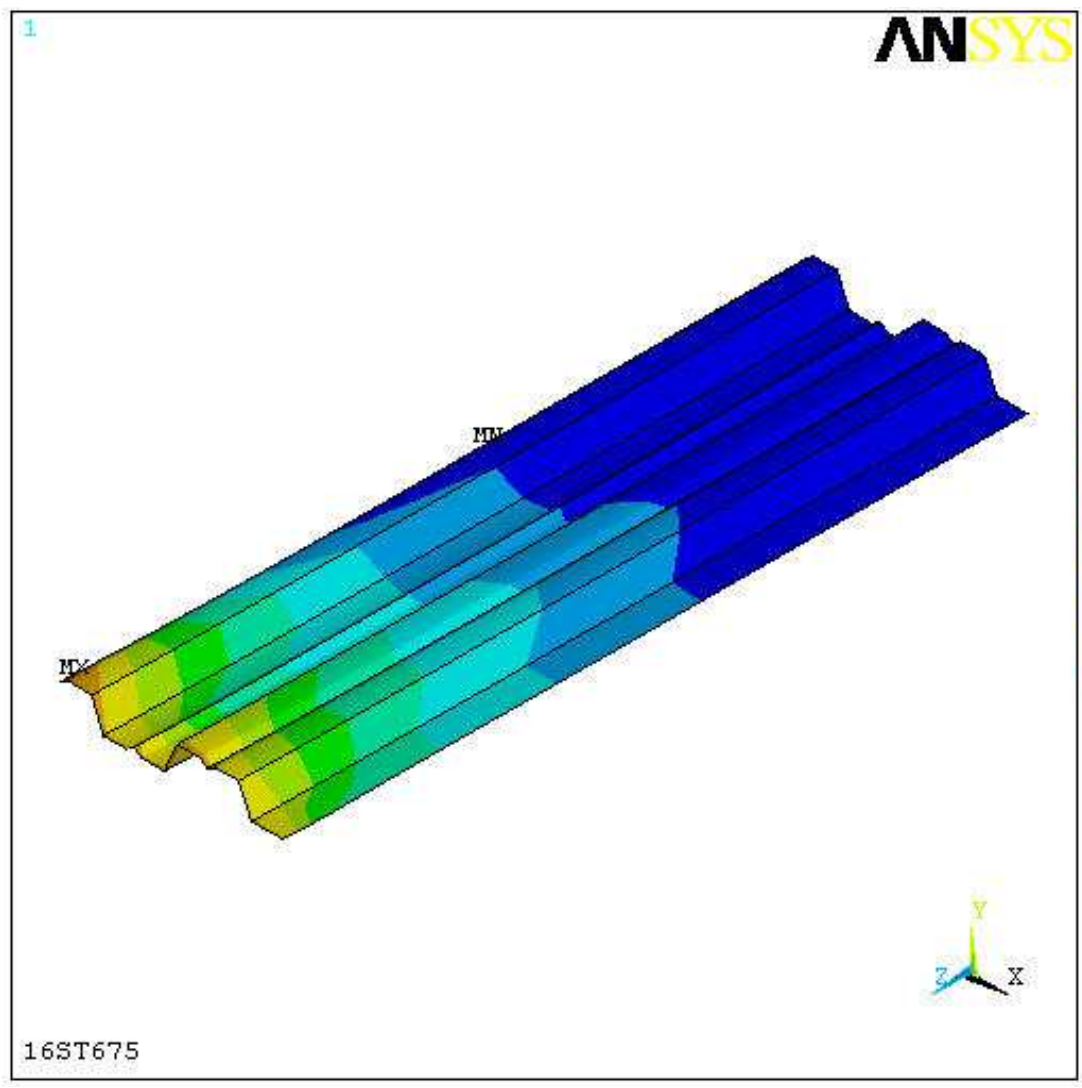

NODHL SOLUTION $\mathrm{TIME}=26$

UY

(AVG)

RSYS $=0$

PowerGraphics

EF ACET $=1$

AVRES $=$ Mat

DMX $=10.461$

$\mathrm{SMN}=-10.46$

$\operatorname{sMX}=2.784$

$-10.46$

$-8.988$

$-7.517$

$-6.045$

$-4.574$

$-3.102$

$-1.63$

$-.1589$

1.313

2.784

Figure 14. Deflection (10.461 mm) of profiled. 


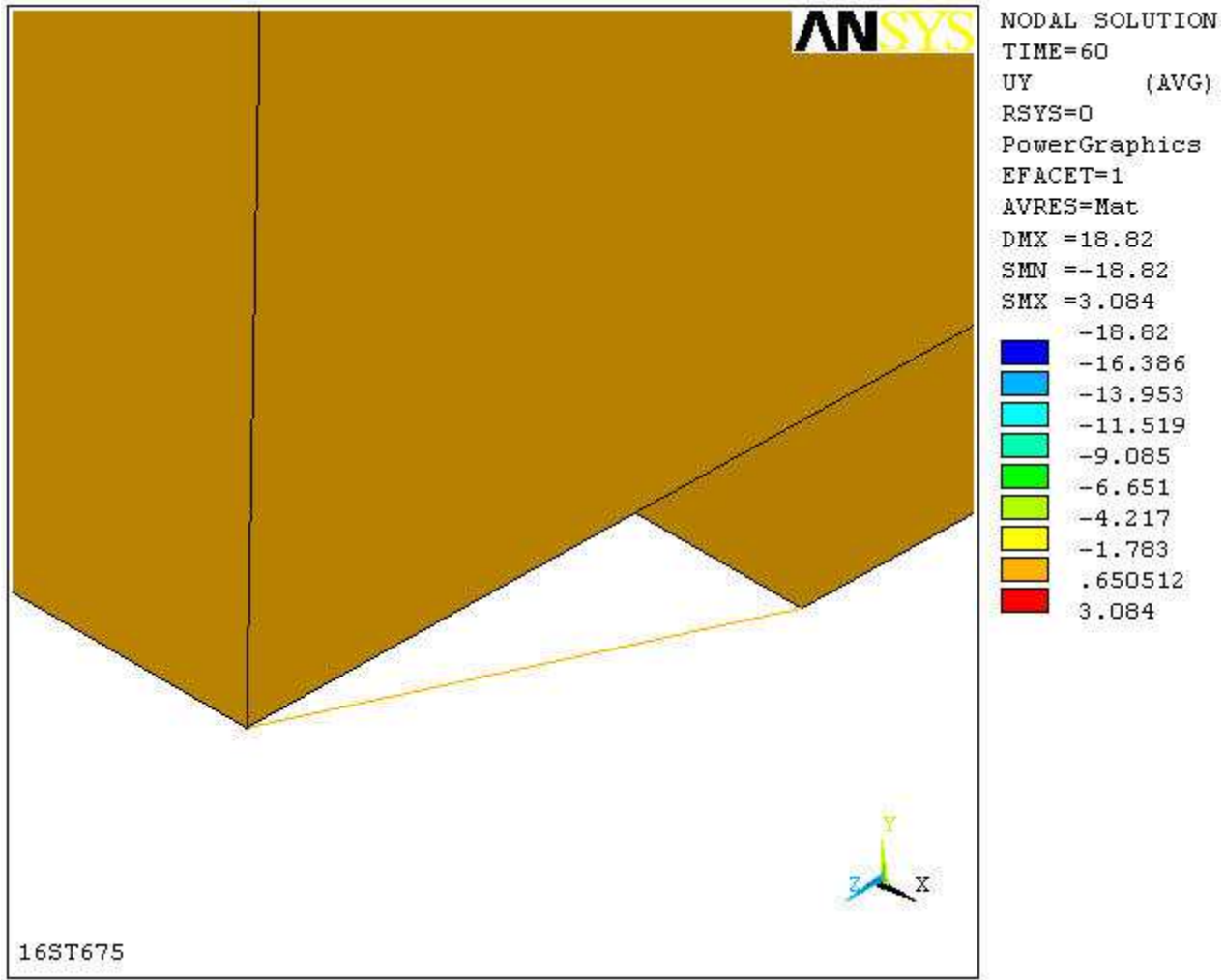

Figure 15. Slip between concrete and steel decking at load of $26 \mathrm{kN}$.profiled steel decking.

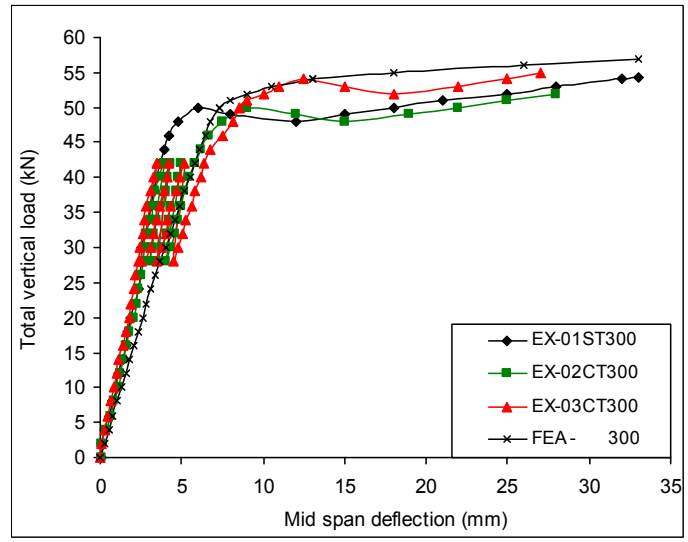

(a) shear span $\left(\mathrm{L}_{\mathrm{s}}\right)=300 \mathrm{~mm}$.

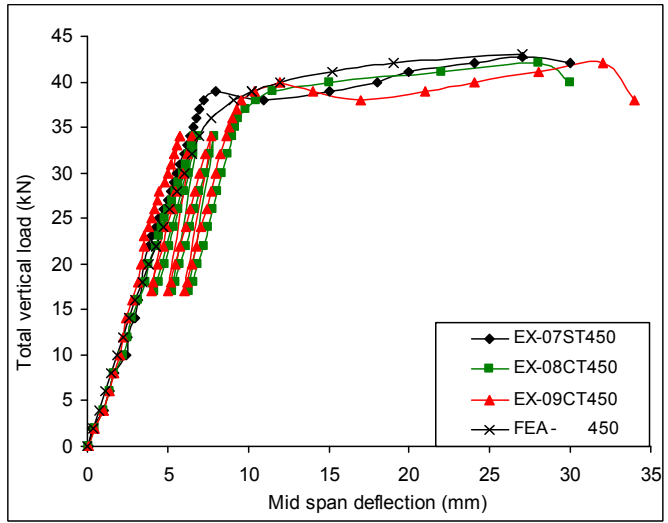

(c) shear span (Ls) $=450 \mathrm{~mm}$.

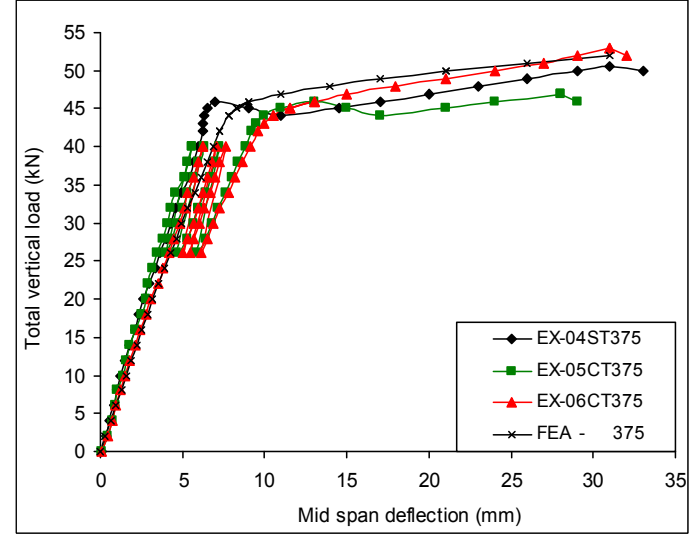

(b) shear span $\left(\mathrm{L}_{\mathrm{s}}\right)=375 \mathrm{~mm}$.

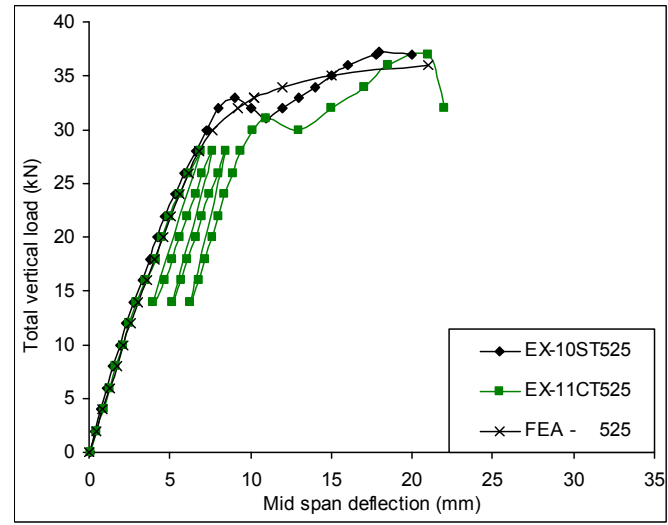

(d) shear span (Ls) $=525 \mathrm{~mm}$. 


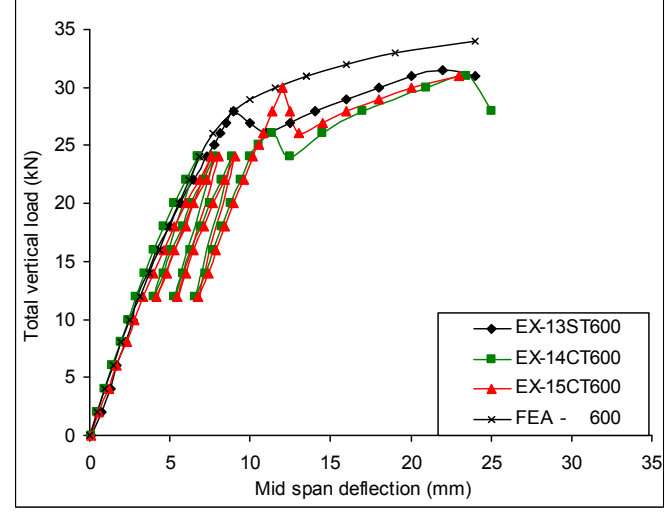

(e) shear span (Ls) $=600 \mathrm{~mm}$.

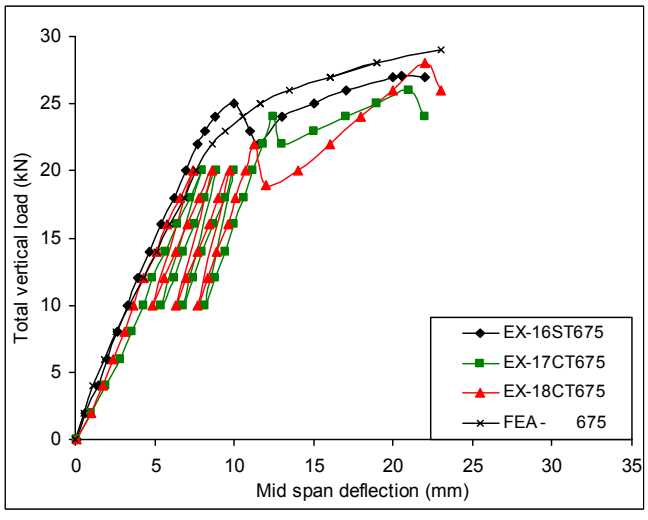

(f) shear span (Ls) $=675 \mathrm{~mm}$.

Figure 16. Experimental \& FE analysis load-deflection curves.

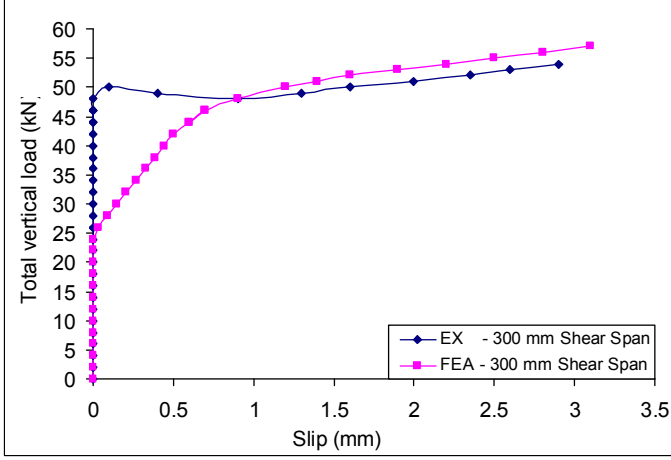

(a) shear span (Ls) $=300 \mathrm{~mm}$.

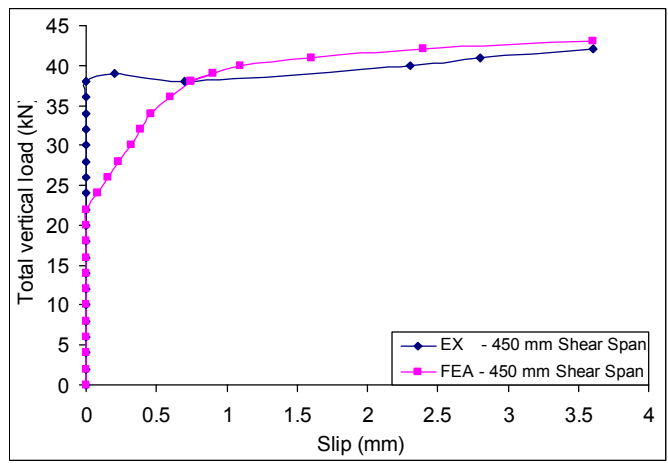

(c) shear $\operatorname{span}(\mathrm{Ls})=450 \mathrm{~mm}$.

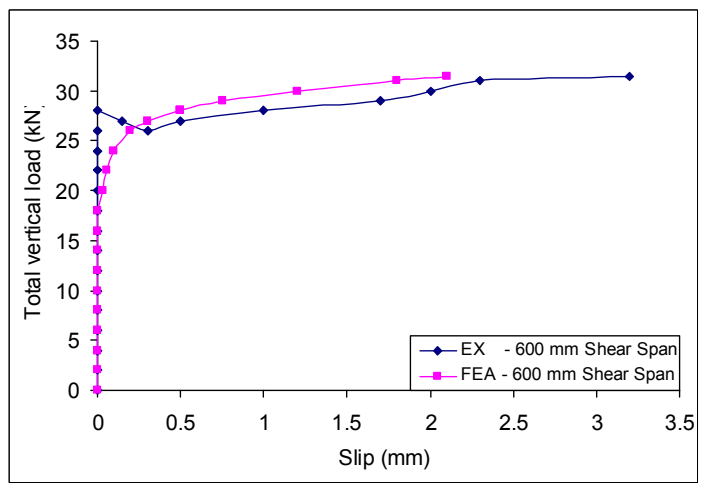

(e) shear span (Ls) $=600 \mathrm{~mm}$.

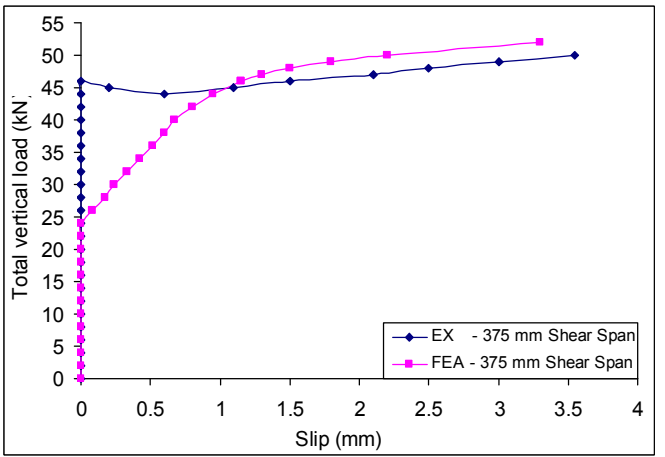

(b) shear span (Ls) $=375 \mathrm{~mm}$.

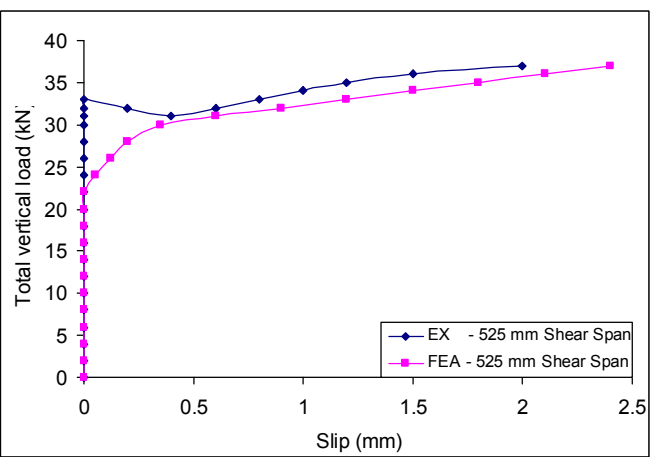

(d) shear span (Ls) $=525 \mathrm{~mm}$.

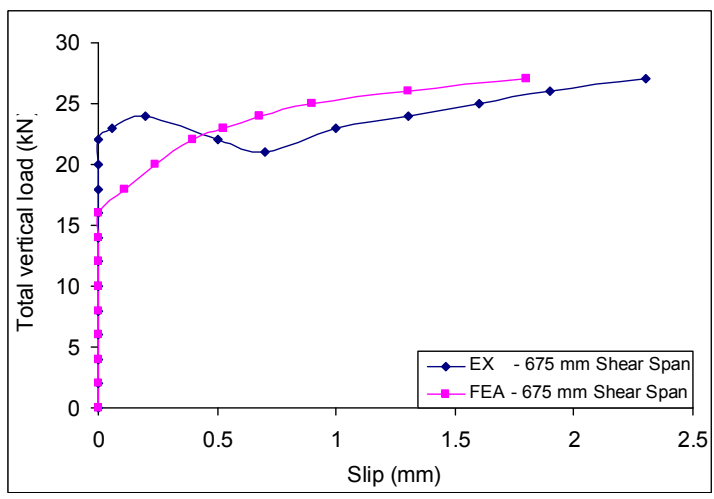

(f) shear span (Ls) $=675 \mathrm{~mm}$.

Figure 17. Experimental \& FE analysis load-end slip curves. 
Table 4. Experimental, FE analysis \& Design load (EC4) results.

\begin{tabular}{|c|c|c|c|c|c|c|c|c|c|c|}
\hline \multirow[b]{2}{*}{$\begin{array}{l}\text { Test } \\
\text { No. }\end{array}$} & \multirow[b]{2}{*}{$\begin{array}{l}\text { Test } \\
\text { specimen } \\
\text { ID No. }\end{array}$} & \multicolumn{5}{|c|}{ Experimental results } & \multicolumn{3}{|c|}{ FE analysis results } & \multirow{2}{*}{$\begin{array}{l}\text { EC4 results } \\
\begin{array}{l}\text { Design Load } \\
(\mathrm{kN})\end{array}\end{array}$} \\
\hline & & $\begin{array}{l}\text { Failur } \\
\text { e load } \\
(\mathrm{kN})\end{array}$ & $\begin{array}{l}\text { Average } \\
\text { failure } \\
\text { load }(k N) \\
\end{array}$ & $\begin{array}{l}\begin{array}{l}\text { Mid span } \\
\text { deflection } \\
(\mathrm{mm})\end{array} \\
\end{array}$ & $\begin{array}{l}\text { Average mid } \\
\text { span deflection } \\
\text { (mm) }\end{array}$ & $\begin{array}{l}\text { Average } \\
\text { Slip }(\mathbf{m m})\end{array}$ & $\begin{array}{l}\text { Load } \\
(\mathrm{kN})\end{array}$ & $\begin{array}{l}\text { Mid span } \\
\text { deflection } \\
(\mathrm{mm})\end{array}$ & $\begin{array}{l}\text { Averag } \\
\text { e Slip } \\
\text { (mm) }\end{array}$ & \\
\hline 1 & 01ST300 & 54.30 & & 33 & & & & & & \\
\hline 2 & $02 \mathrm{CT} 300$ & 52.25 & 53.85 & 28 & 29.33 & 2.9 & 57 & 33 & 3.1 & 55.32 \\
\hline 3 & 03СТ300 & 55.00 & & 27 & & & & & & \\
\hline 4 & $04 \mathrm{ST} 375$ & 50.59 & & 31 & & & & & & \\
\hline 5 & $05 \mathrm{CT} 375$ & 47.10 & 50.23 & 28 & 30 & 3.55 & 52 & 31 & 3.3 & 44.25 \\
\hline 6 & $06 \mathrm{CT} 375$ & 53.00 & & 31 & & & & & & \\
\hline 7 & 07ST450 & 42.65 & & 27 & & & & & & \\
\hline 8 & 08CT450 & 42.00 & 42.18 & 28 & 29 & 3.6 & 43 & 27 & 3.6 & 36.88 \\
\hline 9 & 09СТ450 & 41.90 & & 32 & & & & & & \\
\hline 10 & 10ST525 & 37.19 & & 37 & & & & & & \\
\hline 11 & $11 \mathrm{CT} 525$ & 37.00 & 37.10 & 37 & 37 & 2.0 & 36 & 21 & 2.4 & 31.62 \\
\hline 12 & $12 \mathrm{CT} 525$ & ----- & & -- & & & & & & \\
\hline 13 & 13ST600 & 31.52 & & 24 & & & & & & \\
\hline 14 & 14CT600 & 31.00 & 31.17 & 23.5 & 23.5 & 3.2 & 34 & 24 & 2.1 & 27.65 \\
\hline 15 & $15 \mathrm{CT} 600$ & 31.00 & & 23 & & & & & & \\
\hline 16 & $16 \mathrm{ST} 675$ & 27.10 & & 27 & & & & & & \\
\hline 17 & $17 \mathrm{CT} 675$ & 26.00 & 27.00 & 26 & 27 & 2.3 & 29 & 23 & 1.8 & 24.57 \\
\hline 18 & $18 \mathrm{CT} 675$ & 27.89 & & 28 & & & & & & \\
\hline
\end{tabular}

\section{Comparison Between Experimental and Simulation Results}

The comparison between the experimental and the simulation results are listed below:

- Table 4 shows the comparison between experimental, simulation and EC4 results.

- The failure mode of all composite slab specimens is ductile.

- The load-deflection curve for static and cyclic cases of experiments is in linear range up to $75 \%$ to $80 \%$ of failure load and then turned in to the nonlinear range. This is due to slight decrease in bearing capacity as initial cracks are developed in concrete, progressing almost up to failure due to the mechanical bond between materials. Mechanical interlock originates from the interaction embossments of the profiled steel decking with the concrete. However, load-deflection curve produced by the FEanalysis is in close agreement with the experiment up to the linear range and is slightly less stiff, while in nonlinear range the curve slightly stiffer and seems deviates away from experimental result at the end of applied load (Figure 16). This difference can occur due to the effect of the embossment which play role in the experiment, but is not considered in the FE model.

- A parametric study has been carried out using FE model for different shear span lengths to examine the effect to modeling technique. It can be seen that, the FE models are approximately $6 \%$ higher ultimate loads than the experiments (Figure 16).

- The end slip at the interface of composite slab is monitored after $70 \%$ to $75 \%$ of experimental failure load, and then the rate of end slip is increased till the maximum load is achieved. In case of FE analysis, the end slip is monitored after $45 \%$ to $60 \%$ of the ultimate load, and then the rate of end slip is increased till the failure. It shall be noted that the corresponding end slip values from $\mathrm{FE}$ analysis did not differ appreciably with experimental results (Figure17).

\section{Conclusions}

In the paper, an experimental and simulation investigation of composite slabs with trapezoidal profiled steel decking is presented to investigate theultimate load, load-deflection behavior and load-slip behavior with different shear span lengths. Experimental study is based on Eurocode 4: Part 1.1. The three dimensional non-linear FE modeling and analysis of full-size slabs are carried out by considering the intermediate stiffeners on top and bottom flange of the profiled steel decking and interface contact elements using ANSYS 11 has been studied.

From the observation and experimental data presented above, the following conclusions can be summarized as follows:

- Behavior and strength of composite slab depends mainly on shear span. The ultimate failure load decreases from shorter to longer shear span and moves towards the midspan.

- Application of preliminary cyclic loading is carried out as per provisions in Eurocode 4. However, there is negligible effect of the cyclic loading on the load carrying capacity of the composite slabs as compared to static loading (Figure16).

- Failure modes of all experimental specimens are determined in accordance with the Eurocode 4 
definition and exhibited a ductile failure.

- For shorter shear spans, strength of slab is governed by shear bond failure.

- For shorter to longer shear span, the behavior of slab is governed by shear to flexural failure respectively.

By the comparison of the experimental and simulation results it is found that:

- The ultimate load, load-deflection curve and load-end slip curve of the composite slabs produced by the FE analysis is in close agreement with the corresponding experimental curves and the slope of the curves is identical.

- The FE model proposed in this paper is accurately describes the interaction of concrete and profiled steel decking in a composite slab.

- The FE slip model also has capability to show the separation of concrete slabandsteel decking.

\section{Acknowledgements}

The authors thank Director, VNIT, Nagpur and Head of the Department, Department of Applied Mechanics, VNIT, Nagpur, for their kind support during experimental investigation. The authors express their grateful thanks to Institute for Steel Development and Growth (INSDAG), Kolkata, for sponsoring the research project.

\section{References}

[1] Andrade Vellasco. Standardized composite slab systems for building constructions. Journal of Constructional Steel Research 2004; 60:493-524.

[2] Makelainen P, Sum Y. The longitudinal shear behavior of a new steel sheeting profile forcomposite floor slabs. Journal of Constructional Steel Research 1999; 49:117-128.

[3] Porter ML. Ekberg CE. Design recommendations for steel deck floor slabs. J. Struct. Engg. ASCE. 1976; 102(ST11):2121-2136.

[4] Porter ML, Ekberg CE, Greimann LF, Elleby HA. Shear-bond analysis of steel-deck reinforced slabs. Journal of Structural Engineering, ASCE 1976; 102(12):2255-2268.

[5] Wright HD, Evans HR, Harding PW. The use of profiled steel sheeting in floor construction. Journal of Constructional Steel Research 1987; 7:279-295.

[6] Crisinel M, Marimon F. A new simplified method for the design of composite slabs. Journal of Constructional Steel Research 2004; 60:481-491.

[7] Mohan G. Upadhyay A. Kaushik SK. Simplified design of composite slabs using slip block test. Journal of Advanced Concrete Technology 2005; 3(3):403-412.

[8] Marimuthu V, Seetharaman S. Experimental studies on composite deck slabs to determine the shear-bond characteristic $(\mathrm{m}-\mathrm{k})$ values of the embossed profiled sheet. Journal of Constructional Steel Research 2007; 63:791-803.
[9] Baharom S. Xiao RY. Comparison between modeling of ribbed decking composite slabs with and without slip in finite element analysis. Proceedings of the eighth international conference on computational structures technology, Scotland, 2006; Paper 127:1-13.

[10] Eldip ME, Maaly HM, Beshay AW, Tolba MT. Modeling and analysis of two-way composite slabs. Journal of Constructional Steel Research 2009; 65:1236-1248.

[11] Tsalkatidis T, Avdelas A. The unilateral contact problem in composite slabs: experimental study and numerical treatment. Journal of Constructional Steel Research 2010; 66: 480-486.

[12] Chen S, Shi X. Shear bond mechanism of composite slabs - A universal FE approach. Journal of Constructional Steel Research 2011; 67: 1475-1484.

[13] EN 1994-1-1: Eurocode 4. Design of composite steel and concrete structures- General rules and rules for buildings. Brussels, 2004

[14] BS 5950: Part 4. Structural use of steelwork in building: Code of practice for design of composite slab with profiled steel sheeting. London, 1994.

[15] Oehlers DJ, and Bradford MA. Composite steel and concrete structural members-Fundamental Behaviour. Pergamon Press, 1995.

[16] ASCE. Specification for the design and construction of composite slabs and commentary on specifications for design and construction of composite slabs. (ANSI/ASCE 2-84). New York, 1985.

[17] ANSYS Version 11.0, Reference Manual, USA.

[18] Chen S. Load carrying capacity of composite slabs with various end constraints. Journal of Constructional Steel Research 2003; 59:385-403.

[19] Abdullah, Easterling. Quasi-static analysis of composite slab. Malaysium Journal of Civil Engineering 2007; 19(2), 91-103.

[20] Abdullah Redzuan. Experimental evaluation and analytical modeling of shear bond in composite slab. PhD Dissertation, Virginia Polytechnic Institute and State University, Blacksburg, USA, 2004.

[21] Daniels BJ, Crisinel M. Composite slab behavior and strength analysis. Part I: calculation procedure. Journal of Structural Engineering, ASCE 1993; 119(1):16-35.

[22] Daniels BJ, Crisinel M. Composite slab behavior and strength analysis. Part II: comparisons with test results and parametric analysis. Journal of Structural Engineering, ASCE 1993; 119(1):36-49.

[23] Luttrell LD. Flexural strength of composite slabs. Composite steel structures-advances, design and construction, Elsevier, London, 1987; 106-115.

[24] Widjaja BR. Analysis and design of steel deck-concrete composite slabs. 1997, PhD Thesis USA, Virginia, 1997.

[25] Ellobody Ehab, Young Ben. Performance of shear connection in composite beams with profiled steel sheeting. Journal of Constructional Steel Research 2006; 62:682-694. 